\title{
GLAVNA KONTROLA U PRAVU SRBIJE U PERIODU DO ZAVRŠETKA DRUGOG SVETSKOG RATA
}

\author{
Ljubiša C. Dabić \\ Visoka škola za menadžment i ekonomija u Kragujevcu \\ Predrag Jovićević \\ Univerzitet Privredna akademija u Novom Sadu, \\ Fakultet za primenjeni menadžment, ekonomiju i finansije, Beograd
}

U

ovom istraživanju autor je vođen idejom, s jedne strane, da u jednom relativno kratkom radu analizira i prikaže na celovit način nastanak, uspostavljanje i razvoj glavne kontrole na prostorima nekadašnje i sadašnje Srbije, a s druge, da čitaocima omogući da na jednom mestu sagledaju poreklo, uspostavljanje i nastanak Glavne kontrole, koja se na početku XXI veka razvila u savremenu Državnu revizorsku instituciju, kao najviši organ kontrole javnih finansija u Srbiji.

Predmetno istraživanje je zasnovano na pravno-istorijskom pristupu utvrđivanja porekla, nastanka, uspostavljanja i razvoja vrhovne revizorske institucije u Srbiji u periodu od 1835. do Drugog svetskog rata.

Period do završetka Drugog svetskog rata, koji prevazilazi vremensko trajanje jednog veka, možemo bliže klasifikovati na sledeći način: period od nastanka Glavne kontrole do nastanka države Srba, Hrvata i Slovenaca i period od uspostavljanja Kraljevine Srba, Hrvata i Slovenaca i Kraljevine Jugoslavije do završetka Drugog svetskog rata.

Ključne reči: Glavna kontrola, Državna revizorska institucija, budžetsko pravo, javne finansije

Uvod

vo istraživanje je zasnovano na pravno-istorijskom pristupu ${ }^{1}$ utvrđivanja porekla, nastanka, uspostavljanja i razvoja institucije glavne državne kontrole na prostorima nekadašnje i sadašnje Srbije.

U metodološkom smislu, istraživana tema se dominantno zasniva na normativnom, teorijskom, istorijskom i uporednom metodu, ali se u ovom radu koriste i drugi metodi analiza i sinteza, indukcija i dedukcija i dr.

Ovo istraživanje je zasnovano na: administrativnim aktima, ustavnim, zakonskim i podzakonskim odredbama i relevantnoj, pretežno, pravnoj literaturi.

\footnotetext{
${ }^{1}$ Zorić, M., i Jovanović, V. (2018). Pravno istorijska dimenzija društvenih nauka. Oditor - časopis za Menadžment, finansije i pravo, 4(3), 128-136.
} 
U ovom istraživanju akcenat je stavljen, najpre, na izučavanju pravnog položaja Glavne kontrole - na njene prve i početne oblike, na njeno izvlačenje i „oslobađanje“ iz okrilja izvršne vlasti, sticanje statusa ustavne kategorije, posebnog zakonskog regulisanja, njenog širenja i rasprostiranja na sve prostore tadašnje Kraljevine SHS, odnosno Kraljevine Jugoslavije.

Iz naučnih, pedagoških i praktičnih razloga, u ovom istraživanju izvršena je periodizacija predmeta istraživanja na sledeći način: prvi period se vezuje za uspostavljanje i razvoj Glavne kontrole do nastanka države Srba, Hrvata i Slovenaca, a drugi se nastavlja do Drugog svetskog rata.

\section{Period od nastanka Glavne kontrole do stvaranja države Srba, Hrvata i Slovenaca}

U prvoj polovini XIX veka, tadašnja mala i vazalna Srbija krenula je putem ustavnosti. $U$ to doba ustavi u ovom delu sveta bili su još uvek prava retkost. Donošenjem Sretenjskog ustava (1835), tadašnja Srbija je drugim zemljama bila primer „rano probuđene svesti jednog naroda da uslove za svoj nacionalni i društveni razvoj mora da obezbedi i sopstvenom „konštitucijom“. 2 Međutim, „ustavi Srbije bili su izraz i rezultat burnog, neregularnog, rastrganog političkog razvitka zemlje“, ${ }^{3}$ odnosno donošenje i menjanje ustava u Srbiji bilo je rezultat borbe između vladara i naroda, uključujući i spoljnopolitički faktor. Za tadašnju Srbiju Sretenjski ustav je ima veliki značaj, iako je bio vrlo kratkog veka. Po proteku samo dve nedelje od njegovog usvajanja bio je privremeno, a po proteku nepunih mesec dana i potpuno suspendovan. Ostaće zapamćen po tome što je donet bez učešća Turske, što je u značajnoj meri ograničio vlast Kneza, što je garantovao osnovna građanska prava, a pre svega što je u sistem vlasti uveo Narodnu skupštinu.

Glavna računovodstvena kontrola je postojala u Srbiji još od sredine XIX veka, u tadašnjoj vazalnoj Kneževini Srbiji. Prve odredbe o kontroli javnih rashoda našle su se u prvom Ustavu Kneževine Srbije. Kontrola javnih rashoda je organizaciono bila smeštena u ministarstvu finansija (izvršna vlast), gde je ostala sve do 1843., od kada prelazi u nadležnost Državnog saveta, gde ostaje do 1869.

Prema odredbama Turskog ustava (1838), vrhovni organi vlasti u Srbiji bili su nasledni Knez, centralna vlada koja je brojala tri ministra (unutrašnjih poslova, finansija i pravde) i Državni savet. Državni savet je bio ravnopravan sa Knezom u zakonodavnoj nadležnosti. Narodna skupština se nije pominjala ni kao organ vlasti ni kao savetodavno telo. Međutim, na osnovu donetog Ukaza o Narodnoj skupštini (1839) od strane kneza Miloša, bilo je predviđeno pravo sazivanja Narodne skupštine „po starom običaju kad god potreba ove praznine bude“. ${ }^{4}$ lako je tzv. Turski ustav bio na snazi do 1869., i primenjivan je duže od svih ostalih ustav Srbije, za vreme druge vlade Miloša i Mihaila Obrenovića, mnoge njegove odredbe su faktički stavljene van snage zakonima ustavne prirode. Glav-

\footnotetext{
${ }^{2}$ Miodrag Jovičić, Predgovor, u Ustavi Kneževine i Kraljevine Srbije: 1835-1903 (urednik: Miodrag Jovičić), Beograd: SANU, 1988, str. 8. (u nastavku: Ustavi 1835-1903).

${ }^{3}$ Dragoslav Janković, Razvitak ustavnosti u Srbiji u XIX i početkom XX veka, u Ustavi 1835-1903, str. 12.

${ }^{4}$ Radoš Ljušić, O Ustavu od 1838. godine, u Zborniku radova Ustavni razvitak Srbije u 19. i početkom 20-tog veka, Beograd 1990, str. 30.
} 
Iskustva i pouke iz prošlosti

na kontrola je bila u sastavu Saveta, sa dužnošću da upravlja javnim finansijama i da pregleda račune tri ministra.

Donošenjem posebne uredbe o Glavnoj kontroli (1844), uspostavljena je i organizovana Glavna kontrola umesto dotadašnje Kontrole vladinih računa.

Državni savet je na osnovu Namesničkog ustava (1869) obezvređen kao organ vlasti, jer je izgubio zakonodavnu vlast; u domenu izvršne vlasti nije odlučivao ni o jednom značajnom pitanju. lako je na osnovu odredaba ovog ustava prekinuta funkcionalna veza Glavne kontrole sa Državnim savetom, istovremeno nije uspostavljena njena veza sa Narodnom skupštinom, zbog čega se u ovom periodu ona nalazila uz upravnu vlast i pod njenim uticajem.

$\mathrm{Na}$ osnovu Ustava iz 1888., Glavna kontrola je uspostavljena kao posebno nadleštvo i kao računski sud za pregled državnih računa. Takođe, tim ustavom je stvoren pravni osnov za njeno bliže zakonsko regulisanje. Nešto kasnije, svoju konačnu organizacionu formu Glavna kontrola dobija u posebnom zakonu (1892). Tako uspostavljena zakonska rešenja su zadržana sve do ujedinjenja u Kraljevinu SHS (1921). Sa dve načelne odredbe Glavna kontrola je bila uređena i oktroisanim Ustavom iz 1901, uz neznatno jačanje njene samostalnosti, u odnosu na odredbe Ustava iz 1888. Ustavom iz 1903. je u suštini preuzeta osnovna sadržina ustava iz 1888., iako su izvršene određene izmene. Ovaj ustav je ostao nepromenjen sve do 1918, kada je na jugoslovenskim prostorima izvršeno ujedinjenje, stvaranjem Kraljevine SHS.

U nastavku rada, ovaj period može se sistematizovati i obraditi kroz sledeća pitanja: stvaranje pravnih pretpostavki za uspostavljanje Glavne kontrole; formalno uspostavljanje Glavne kontrole; uspostavljanje Glavne kontrole kao ustavne kategorije; zakonsko i podzakonsko regulisanje Glavne kontrole i pravna priroda Glavne kontrole.

\section{Stvaranje pravnih pretpostavki za uspostavljanje Glavne kontrole}

Sretenjskim ustavom (1835) su postavljeni temelji za glavnu finansijsku kontrolu u Kneževini Srbiji, u posebnom X poglavlju („O finansiji/aznadarstvu/“). Stavljeno je u dužnost Knezu i Državnom savetu da uspostave „glavnu račundžinicu“, koja bi pregledala sve račune finansija i nadzirala da se narodni novac ne troši za druge namene, osim za one, koje su odobrene od strane Narodne skupštine. ${ }^{5} \mathrm{U}$ kontekstu našeg predmeta istraživanja, tadašnji ustavotvorac je glavnu kontrolu organizaciono poverio Knezu i Državnom savetu, sa prevagom na skupštinsku vlast. Narodna skupština je bila zakonodavni činilac ${ }^{6}$ samo u finansijskoj oblasti, jer se bez njenog pristanka ne bi mogao „naložiti ili udariti ... nikakav danak“. ' Međutim, nezavisno od postojanja ovakvog ustavnog rešenja, u praksi je postojalo

\footnotetext{
${ }^{5}$ Ustav Knjažestva Serbije od 1835., čl. 107, u Ustavi i vlade Kneževine Srbije, Kraljevine Srbije, Kraljevine SHS i Kraljevine Jugoslavije (1835-1941), Beograd 1988, str. 38 (u nastavku: Ustavi i vlade 1835-1941).

${ }^{6}$ Vidovič, Z., \& Milunović, M. (2017). Revizija svrsishodnosti poslovanja. Oditor - časopis za Menadžment, finansije i pravo, 3(2), 37-53.

${ }^{7}$ Dragoljub Popović, Ustav od 1835. godine - „Sretenjski ustav“, u „Ustavi Kneževine i Kraljevine Srbije: 1835-1903", str. 41.
} 
rešenje u Ukazu o uspostavljanju Državnog saveta od 14. februara 1835., na osnovu koga je ministar finansija bio dužan da svake godine podnosi račune o svim državnim prihodima i rashodima Savetu, Knezu i Narodnoj skupštini. ${ }^{8}$ Zbog toga se mora konstatovati da stvaranje ustavnog osnova nije bila dovoljna pretpostavka da se u praksi uspostavi glavna račundžinica, već je to učinjeno tek posle donošenja tzv. Turskog ustava (1838). ${ }^{9}$ Ona nije uspostavljena u praksi zbog postojanja permanentne međusobne borbe između Kneza i Saveta, a Knez nije želeo da svoju apsolutnu vlast okrnji, zbog čega je bio protiv Ustava i nije mario za Državni savet. ${ }^{10}$ Sve dok nije uspostavljenja glavna račundžinica, njene poslove vršio je Savet, koji je prema Ustrojstvu od 29. juna 1835, bio dužan da svake godine sastavlja „opšti pregled računa o učinjenim državnim troškovima“. ${ }^{11}$

Ustav Kneževine Srbije iz 1838. (tzv. Sultanski hatišerif) donet je posle ukidanja Sretenjskog ustava. On je zadržao samo načelne odredbe o Glavnoj kontroli u tadašnjoj Srbiji. Prvo, Savetu je dato pravo da svake godine (u mesecu martu i aprilu) zahteva od tri „popečitelja“ (ministara unutrašnjih poslova, finansija i pravosuđa i prosvete) da podnesu svoje izveštaje o poslovanju za tekuću godinu, i da pregleda njihove račune. Drugo, tri ministra bila su dužna da svake godine sastave izveštaj o svim poslovima koji su vođeni u njihovim kancelarijama, i o onim koji su vršeni na njihovim područjima, sa iznetim dokazima, i podnesu ga sa svojim pečatima i potpisima. ${ }^{12}$ Treće, Savetu je stavljeno u dužnost da upravlja javnim finansijama i da pregleda račune tri ministra. Savet je bio državni organ kome su stavljena u nadležnost značajna ovlašćenja, naročito u zakonodavnoj i upravnoj materiji, bez obzira na činjenicu što se u Ustavu ni na jednom mestu izričito nije pominjao kao najviši organ vlasti, već samo kao telo koje rešava o javnim interesima i pomaže Knezu. Savet je u zakonodavnoj nadležnosti bio ravnopravan organ sa Knezom.

$\mathrm{Na}$ osnovu odredaba Turskog ustava (1838), po prvi put je u praksi bilo ustanovljeno naročito odeljenje pri ministarstvu finansija, pod nazivom Račundžinica praviteljstvena ili Glavna kontrola, sa zadatkom „da vrši pregledanje svih računa pod nadzorom praviteljstvenim stojećih zemaljskih kasa od prihoda i rashoda“. Ministar finansija bio je dužan da podnosi na odluku Savetu zaključene, sklopljene i pregledane račune. ${ }^{13}$

I Uredbom o uspostavljanju Saveta Kneževine Srbije od 27. aprila 1839., posebnom odredbom, Savetu je dato pravo da svake godine zahteva od tri ministra da podnesu izveštaje o njihovim poslovima za proteklu godinu. U zavisnosti od osnovanosti pronađenih nedostataka, Savet je ili svakog ministra pojedinačno od odgovornosti oslobađao ili in je na odgovornost pozivao. Kako se zloupotrebe ne bi širile i uvećavale, ukoliko bi Savet u tekućoj godini

\footnotetext{
${ }^{8}$ Stojan Marković, Administracija Kraljevine Srbije sa naročitim pogledom na Nauku o državi i državnoj upravi, Knjiga prva - Opšti deo, Beograd 1893, str. 416.

${ }^{9}$ Milan Radojković, Kontrola budžeta (doktorska disertacija), Beograd 1940, str. 55.

${ }^{10} \mathrm{Na}$ osnovu Uredbe od 29. januara 1835., koju je doneo Državni savet, Knez je bio dužan da jednom godišnje dođe na sednicu Saveta i da na njoj opširno podnese izveštaj o svim državnim poslovima, o stanju celokupnog naroda, o opštem pregledu računa o učinjenim državnim troškovima, radi podizanja nivoa upravljanja u ovim oblastima i kako bi se narodno blagostanje podiglo. Ustroenie Državnoga sovjeta (1835), čl. 8, u Alek. Popović, Odluke Glavne kontrole Kraljevine Srba, Hrvata i Slovenaca i zakonodavstvo o Glavnoj kontroli, Beograd 1926, str. 113-114.

${ }^{11}$ Kosta Kumanudi, Administrativno pravo, Beograd 1921, str. 134.

${ }^{12}$ Ustav Knjažestva Serbije od 1838., čl. 15 i 26, u Ustavi i vlade 1835-1941, str. 55-56.

${ }^{13}$ Milan Radojković, op. cit., str. 55.
} 
primetio kakvu zloupotrebu, imao je dužnost da opomene konkretnog ministra, da od njega zatraži objašnjenje, a u slučaju potrebe preduzme i nužne mere, u dogovoru sa Knezom.

Uredbom o organizaciji centralne uprave Kneževine Srbije od 29. maja 1839., u okviru ministarstva finansija bila su dodirnuta ili uređena pojedina pitanja Glavne kontrole. Prvo, sve dužnosti ministra finansija su se iscrpljivale u tri vrste poslova koje je obavljao, i to: 1) Glavna blagajna („kasa“) opštenarodna ili Državna blagajna („Kaznačejstvo“), 2) Račundžinica vladina ili Glavna kontrola, i 3) industrijsko bankarstvo („Promišljenost finansielna“). Drugo, u odeljenju Glavne kontrole bili su nadležni da pregledaju sve račune prihoda i rashoda koji su bili pod nadzorom Državne blagajne, i to: kontrolu Glavne blagajne opštenarodne, pregled i ispitivanje njenih računa, i kontrolu, pregled $\mathrm{i}$ ispitivanje svih u Zemlji koji se nalaze ispod (okružne, đumručke i ostalih blagajni i njihovih računa) po povremenim redovnim izveštajima, ali i vanrednim. Treće, od osoblja, za Glavnu kontrolu su bili određeni: jedan načelnik, dva računoispitivača i jedan zapisničar koji je ujedno bio i registrator i arhivar. ${ }^{15}$

Da zaključimo. Na osnovu interpretiranih odredaba podzakonskih propisa, Glavna kontrola se organizaciono nalazila u sastavu izvršne vlasti, bliže u sastavu ministarstva finansija.

$\mathrm{Na}$ osnovu Ukaza Savetu Kneževine Srbije od 6. oktobra 1843., koji je doneo Knez Aleksandar Karađorđević, saglasno predlogu Saveta, rešeno je da se odeljenje Glavne kontrole pri ministarstvu finansija ukine i u Savet izmesti. Prvo, na osnovu odredbe Turskog ustava, predmetnim ukazom odlučeno je da se Glavna kontrola iz ministarstva finansija premesti u Savet, u čijoj bi organizaciji od jeseni poslovala pod imenom Računsko-kontrolna komisija („Računoispitatelna Komisija“). Drugo, bilo je predviđeno da će ova kontrola imati poseban pečat sa natpisom Kontrola vladinih računa („Kontrola Pravitelstvennih računa") ${ }^{16}$. Donošenjem navedenog ukaza, Glavna kontrola je po prvi put izašla iz okrilja ministarstva finansija, tj. izvršne vlasti i organizaciono je smeštena u Državni savet.

\section{Formalno uspostavljanje Glavne kontrole}

Glavna kontrola je bila jedno od najstarijih nadleštava obnovljene Srbije. Ustanovljena je 1844., a predviđena još u prvom srpskom ustavu. ${ }^{17}$ Najpre je bila smeštena u sastavu ministarstva finansija (1843), a sa ostvarenom pobedom Saveta nad Knezom, ona je ukazom Kneza premeštena u Savet (1843), da bi naredne godine postala odeljenje Državnog saveta, tada organa zakonodavne vlasti, pod nazivom Kontrola vladinih računa (1844).

Donošenjem Uredbe o uspostavljanju Glavne kontrole od 14. jula 1844. (doneta od Kneza Aleksandra Karađorđevića uz saglasnost Saveta), ${ }^{18}$ uspostavljena je i organizovana Glavna kontrola umesto dotadašnje Kontrole vladinih računa. U pogledu njenog pravnog položaja, ona je organizaciono ostala u sastavu Saveta, poslovala je pod njegovim nadzorom i nastupala u njegovo ime. To potvrđuju i pravna rešenja o personalu Glavne kontrole.

\footnotetext{
${ }^{14}$ Ustroenie Sovjeta Knjažestva Srbskog (1839), čl. 24-25, u Alek. Popović, op. cit., str. 114-115.

${ }^{15}$ Ustroenie Centralnoga Pravlenia Knjažestva Srbskog od 29. maja 1839., čl. 4, 7. i 15, u Alek. Popović, op. cit., str. 115.

${ }^{16}$ Ukaz Sovjetu Knjažestva Srbskog od 6 oktobra 1943. godine, u Alek. Popović, op. cit., str. 116.

${ }^{17}$ Laza Kostić, Komentar Ustava Kraljevine Jugoslavije od 3 septembra 1931 (Jugoslovensko ustavno pravo), Beograd 1934, str. 268.

${ }^{18}$ Ustrojenie Glavne kontrole od 14. jula 1844., u Alek. Popović, op. cit., str. 116-124.
} 
Osnovni zadaci Glavne kontrole bili su da pregleda $\mathrm{i}$ ispituje račune svih prihoda $\mathrm{i}$ rashoda državnih, opštinskih i svih drugih javnih institucija. Od ovog pravila učinjen je izuzetak za račune onih javnih institucija koji bi voljom osnivača bili izuzeti od pregleda. $\mathrm{Na}$ osnovu svih podnetih i pregledanih računa, Glavna kontrola je bila dužna da sastavi glavne uporedne preglede iz kojih se moglo sagledati: kakvi su i koliki prihodi i rashodi, da li su se oni uvećavali ili umanjivali, i da li se pri rukovanju njihovom vodilo računa o javnoj koristi koju je trebalo realizovati. Bilo je predviđeno da Glavna kontrola vrši periodičnu (redovnu) kontrolu, ali joj je bilo dopušteno da vrši i tzv. vanrednu kontrolu, tj. iznenadnu posetu nekoj od blagajni koje su ulazile u njenu nadležnost. Ostavljeno je da se kasnije preciziraju odredbe o vršenju ovih vrsta kontrole.

Kakav je bio odnos Glavne kontrole prema Savetu i drugim nadleštvima? Najpre, već smo konstatovali da je ona radila pod neposrednim nadzorom Saveta i nastupala je u njegovo ime. Takođe, poslovala je pod imenom Saveta, imala je dužnost da ga češće o svemu izveštava i da daje preporuke da se zakonskim putem preduzmu potrebna sredstva radi boljeg sistema u ostvarivanju prihoda, lakšeg i pravilnijeg razrezivanja poreza prema narodu, nadgledanja štedljivosti u izdacima, boljeg načina upravljanja blagajnom i računima. Štaviše, ona je bila dužna da Savetu podnosi na uvid izvode uporednih pregleda koje je sastavljala. Znači, Glavna kontrola je bila u svakom pogledu zavisna, podređena i nesamostalna u odnosu na Savet. Zatim, sa svim ministarstvima morala je biti u „dogovornom odnosu", kako bi se dogovorom i saglasnošću sa svim nadleštvima računovodstvo u Srbiji dovelo u bolje i celishodnije stanje. Dalje, ima je dužnost da sa svim drugim nadleštvima i licima neposredno vodi prepisku, ako je to nužno, kako bi se dala objašnjenja za otklanjanje ili popravljanje uočenih nepravilnosti u njihovom radu. Da zaključimo: u ovom periodu ne može se govoriti o samostalnosti i nezavisnosti Glavne kontrole od izvršne i upravne vlasti.

Navodimo neke od odredaba organizacije Glavne kontrole kojima se pokazuje njena nesamostalnost, podređenost i zavisnost od Saveta. Prvo, svaki akt koji je izlazio iz Glavne kontrole morao je potpisati njen upravitelj, tj. član Saveta, a u slučaju njegove sprečenosti, Savet je imao pravo da odredi drugog člana koji će ga za vreme sprečenosti u dužnostima zastupati. Drugo, svi računi ministarstava podnosili su se kao i do tada, na ime Saveta, koje će on predavati Glavnoj kontroli na pregled i ispitivanje. Treće, Glavna kontrola je imala obavezu da se sa ministrima dogovori o redosledu i vremenu dostavljanja računa na pregled i ispitivanje.

Napred navedena uredba zamenjena je novom Uredbom o uspostavljanju Glavne kontrole od 15. septembra 1858., kojom su izvršene određene promene u odnosu na prethodnu, i to: povećan je broj računoispitača; predsednik i članovi Glavne kontrole su postavljani na predlog samog Saveta, ostali personal na predlog Glavne kontrole, a komesar na predlog ministra finansija, uz utvrđivanje uslova za njihovo postavljenje; predsednik i članovi Glavne kontrole bili su nezavisni od državnih organa, a zavisni jedino i isključivo od Državnog saveta. Glavna kontrola je dobila ograničene ingerencije u postavljanju njenog personala. Uredba o Glavnoj kontroli je ukinuta, samo posle dve godine, na osnovu uredbe od 16. februara 1860., zbog toga što se po nahođenju tadašnje zakonodavne vlasti pokazalo da Glavna kontrola nije bila prema tadašnjim potrebama. Zbog toga je ona ušla u sastav Državnog saveta. ${ }^{19}$ Ova uredba je ukinuta novodonetom Ured-

${ }^{19}$ Stojan Marković, op. cit., str. 419-420. 
bom o uspostavljanju Glavne kontrole od 27. februara 1862., koja je opet bila predmet izmena nekoliko puta (dva puta 1868, 1878. i 1879). ${ }^{20}$

Značajno je napomenuti da je donošenju Namesničkog ustava (1869) prethodilo donošenje većeg broja zakona čijim su odredbama u najvećoj meri izmenjena rešenja Ustava iz 1838. - zakoni o uspostavljanju i organizaciji: Državnog saveta (1861), Narodne skupštine (1861), Centralne državne uprave u Knjažestvu Srbiji (1862) i dr.

Ustav za Knjažestvo Srbiju (1869) donet je na Velikoj narodnoj skupštini koja je zasedala u Kragujevcu. Ovaj najdugotrajniji srpski ustav u XIX veku, Srbija je samostalno donela. U kontekstu našeg predmeta istraživanja, ovim ustavom su regulisana pitanja o državnom imanju, o knjaževom imanju i knjaževoj civil-listi, ali ne i pitanje državne kontrole javnih finansija. Zbog toga se može konstatovati da su ove ustavne odredbe, u vrednosnom smislu, po pitanju kontrole javnih finansija predstavljale nazadovanje u odnosu na odredbe iz prethodnog ustava. ${ }^{21}$ Ipak, Državni savet je od Glavne kontrole mogao zahtevati „potrebne izveštaje i objašnjenja o državnim računima“. ${ }^{22}$ Međutim, kako je primećeno u pravnoj teoriji, navedena ustavna odredba bi imala smisla i vrednost samo uz postojanje druge ustavne ili zakonske odredbe, na osnovu koje bi Državni savet bio dužan da pomenute izveštaje i objašnjenja Glavne kontrole o državnim računima prethodno pregleda, proučava, ocenjuje i da ih sa svojim izveštajima i primedbama podnese Narodnoj skupštini, kao organu u vršenju zakonodavne nadzorne državne vlasti. ${ }^{23}$ Zbog toga se u literaturi pronalazi stav da je veliku prekretnicu u položaju Glavne kontrole predstavljao ustav iz 1869., jer se nakon njegovog donošenja izgubila veza Glavne kontrole sa Državnim savetom, koji više nije bio nadležan da donosi bilo kakve odluke o računima. Državni savet je prestao biti zakonodavni organ, a zakonodavna vlast je prešla u ruke Narodne skupštine sa Knezom. lako je prekinuta funkcionalna veza Glavne kontrole sa Državnim savetom, istovremeno nije uspostavljena veza sa Narodnom skupštinom, zbog čega se u ovom periodu ona nalazila uz upravnu vlast i pod njenim uticajem. ${ }^{24}$

Na osnovu Namesničkog ustava, u pogledu Glavne kontrole stvorena je osetna praznina, sa praktičnim posledicama na urednost, pravilnost i zakonitost u rukovanju državnim finansijama i državnim prihodima i rashodima. lako je Narodnoj skupštini bilo priznato ustavno pravo da se bez njenog odobrenja ne može „ni u kom slučaju danak ili opšti prirez ustanoviti“, ali joj je praktično bila oduzeta pravna i stvarna mogućnost vršenja vrhovne kontrole u rukovanju državnim finansijama. Zbog toga se Glavna kontrola u praksi javlja kao čisto računska služba, koja je bila potčinjena upravnoj vlasti, a bez ustavnih garancija za njenu samostalnost. ${ }^{25}$

U kontekstu budžetskog prava, ustavom iz 1869. bilo je utvrđeno da se bez odobrenja Narodne skupštine nije mogao nikakav danak ili porez uvoditi, ali ni postojeći preinačiti. Međutim, iako je skupština imalo budžetsko pravo, kao najjače i najvažnije sredstvo

\footnotetext{
${ }^{20}$ Preteču uspostavljene Glavne kontrole u tadašnjoj Srbiji, na osnovu Ustava iz 1888., predstavlja doneti akt o „organizaciji Glavne kontrole“ od 27. februara 1862., koji je prestao da važi donošenjem Zakona o uređenju Glavne kontrole (1892). Zakon o uređenju Glavne kontrole, Beograd 1892, čl. 149. stav 1.

${ }^{21}$ Ustav za Knjažestvo Srbiju od 1869., čl. 93-98, u Ustavi i vlade 1835-1941, str. 84.

${ }^{22}$ Ustav za Knjažestvo Srbiju iz 1869., čl. 90. stav 1. tač. 13.

${ }^{23}$ Stojan Marković, op. cit., str. 422-423.

${ }^{24}$ Milan Radojković, op. cit., str. 56.

${ }^{25}$ Stojan Marković, op. cit., str. 423.
} 
kontrole zakonodavne vlasti nad vladom, nije u dovoljnoj meri bilo priznato parlamentarnoj vlasti. Skupština je zaista bila ovlašćena da odlučuje o podnetom budžetu od strane vlade, s tim da po ustavnom rešenju nije imala pravo da ga odbije, tj. morala je u praksi da primi budžet onako kako je predložen od vlade.

\section{Uspostavljanje Glavne kontrole kao ustavne kategorije}

U Srbiji je Glavna kontrola kao ustavna kategorija po prvi put uspostavljena Ustavom iz 1888, kao „osobeno nadleštvo“ i kao „računski sud“ za pregled državnih računa. ${ }^{26} \mathrm{Ta}$ kođe, ustavom je stvoren pravni osnov za njeno zakonsko regulisanje, jer je bilo predviđeno da će se zakonom bliže odrediti njena organizacija i nadležnosti, kao i način na koji će se postavljati njeno osoblje.

U strukturalnom smislu, Glavna kontrola je imala predsednika i četiri člana, koje je birala Narodna skupština sa kandidacione liste koju je sastavljao Državni savet, a na kojoj je bilo predloženo dva puta više kandidata od broja koji se birao. Članovima Glavne kontrole priznavao se status sudije Kasacionog suda, a njenom predsedniku položaj tadašnjeg člana Državnog saveta, koji se postavljao na funkciju doživotno. Po prvi put su Državni savet i Glavna kontrola organizovani na taj način da mogu nadzirati i kontrolisati upravnu vlast, u granicama zakona i budžeta, a na lični sastav ovih organa Skupština je imala presudan uticaj.

Ustavom su bili uređeni i uslovi koje je moralo da ispuni lice koje se bira za člana Glavne kontrole. Zahtevalo se da predsednik i dva člana Glavne kontrole budu sa pravničkim obrazovanjem. Predsednik i članovi Glavne kontrole su imali ustavom zagarantovan položaj u pogledu „nepokretnosti u svojim zvanjima“, jer nisu mogli biti otpušteni iz državne službe bez presude redovnih sudova, niti premešteni u druga zvanja bez svog pristanka, a u penziju su išli samo ako su navršili 40 godina državne službe ili 65 godina života, ili ako su teško oboleli. Na kraju, ustavom su utvrđene i osnovne nadležnosti Glavne kontrole, koje su se ogledale u sledećem: vršila je pregled, ispravljala i likvidirala račune opšte administracije i svih računopolagača prema državnoj blagajni; nadzirala je da se ne prekorači nijedan izdatak iz budžeta i da se ne dogodi nikakvo prenošenje suma iz jedne budžetske partije u drugu; odobravala je („završuje“) račune svih državnih uprava i bila dužna da prikupi sve potrebne dokaze i obaveštenja. Opšti državni račun podnosio se Narodnoj skupštini sa primedbama Glavne kontrole, i to najdalje za dve godine, računajući od završetka svake budžetske godine.

Glavna kontrola nije imala svojstvo pravnog lica, već je bila posebno nadleštvo u sastavu ministarstva finansija. Ona je imala i položaj računskog suda. Akti koje je donosila Glavna kontrola imali su snagu konačnih akata, s tim da je ostavljeno zakonodavcu da bliže odredi u kojim je slučajevima protiv njenih odluka bila dopuštena žalba Kasacionom sudu. Ustavom je uspostavljen određeni stepen nezavisnosti i samostalnosti Glavne kontrole u odnosu na izvršne i upravne organe vlasti kroz način izbora njenog predsednika i članova kao i garantovanjem njihovog položaja.

U kontekstu našeg predmeta istraživanja, Ustavom su u posebnom odeljku regulisana pitanja državnih finansija, državne ekonomije i državnog imanja, a u jedanaestom

\footnotetext{
${ }^{26}$ Ustav za Kraljevinu Srbiju od 1888., čl. 180-182, u Ustavi i vlade 1835-1941, str. 128-129.
} 
Iskustva i pouke iz prošlosti

odeljku isključivo pitanje o Glavnoj kontroli. ${ }^{27}$ Puno budžetsko pravo Narodna skupština je ostvarila na osnovu Ustava od 1888., uporedo sa uspostavljanjem parlamentarizma u tadašnjoj Srbiji. Na osnovu ustavne odredbe obezbeđeno je skupštini da svake godine na svojoj sednici odobrava jednogodišnji budžet, kao i da joj se podnosi završni račun. ${ }^{28}$

Glavna kontrola ${ }^{29}$ je sa dve načelne odredbe uređena i oktroisanim Ustavom iz 1901., uz neznatno jačanje njene samostalnosti. Bilo je predviđeno da se njena organizacija uređuje posebnim zakonom na "načelu samostalnosti“. U poređenju sa ustavnim rešenjima iz 1888, Glavna kontrola nije više „osobeno nadleštvo“, a ostala je kao „računski sud“ sa većim stepenom samostalnosti u odnosu na ministarstvo finansija. $\mathrm{Na}$ osnovu načela samostalnosti bilo je predviđeno da se njena organizacija uredi posebnim zakonom. ${ }^{30}$ Ovim ustavom su sužena neznatno prava Monarha u odnosu na njegova ovlašćenja iz Ustava iz 1869. Monarh više nije pretežni činilac zakonodavne vlasti, jer više nije imao isključivo pravo zakonodavne inicijative.

Ustavom iz 1903. je u suštini preuzeta osnovna sadržina ustava iz 1888, iako su izvršene određene izmene. ${ }^{31} \mathrm{U}$ kontekstu našeg predmeta istraživanja, ostale su u osnovi iste odredbe iz Ustava iz 1888., sa neznatnim preciziranjima i izmenama. ${ }^{32}$ Donošenjem ovog ustava završava se borba demokratskih, parlamentarnih težnji u Srbiji sa Knezom, pobedom tih težnji i uspostavljanjem parlamentarizma u Srbiji. Takođe, ovim ustavom je ponovo uspostavljena puna supremacija skupštine u oblasti donošenja i izvršenja budžeta. Donošenje novog Zakona o državnom računovodstvu usledilo je 1910, pretežno na iskustvima francuskog budžetskog sistema. ${ }^{33}$

Od 1903. bilo je nekoliko predloga za promenu ustava (1907, 1909. i dva 1910), ali nijedan od sačinjenih predloga nije postao predmet skupštinskog izjašnjavanja. U narednom periodu, Srbija je sa saveznicima prošla kroz dva balkanska rata (1912-1914). Rezultat balkanskih ratova za Srbiju se ogledao u teritorijalnom proširenju na tzv. Staru Srbiju. Kraljevskim ukazom od 3. decembra 1913., samo delimično je protegnuto važenje ovog ustava na prostore Stare Srbije. Odredbe ustava iz 1903. zatekle su Srbiju u vreme vođenja Prvog svetskog rata (1914-1918).

\section{Zakonsko i podzakonsko regulisanje Glavne kontrole}

Prvi Zakon o uređenju Glavne kontrole u Srbiji donet je 1892, na osnovu Ustava iz 1888 , a bio je nekoliko puta predmet izmena i dopuna $\left(1893,1894\right.$. i 1897). ${ }^{34}$ Za izvršenje ovog zakona Opšta sednica Glavne kontrole donela je, najpre, Pravila i naredbe za

\footnotetext{
${ }^{27}$ Ustav za Kraljevinu Srbiju od 1888. , čl. 171-182, u Ustavi i vlade (1835-1941), str. 127-129.

${ }^{28}$ Ustav za Kraljevinu Srbiju iz 1888., čl. 174-175.

${ }^{29}$ Duin, D., Krstić, D., Nešić, B., \& Kaluđerović, N. (2017). Revizija svrsishodnosti javnih nabavki budžetskih korisnika. Oditor - časopis za Menadžment, finansije i pravo, 3(3), 61-72.

${ }^{30}$ Ustav Kraljevine Srbije od 1901. godine, čl. 96, u Ustavi i vlade 1835-1941, str. 160.

31 „... Novi ustav (misli se na Ustav iz 1903. - LJ. D.) je nastao kombinovanjem pojedinih odredaba Ustava od 1869. i Ustava od 1888." Mirko Mirković, Ustav od 1903. godine, u Ustavi 1835-1903, str. 190.

${ }^{32}$ Ustav za Kraljevinu Srbiju od 1903., čl. 173-174. i 179-181, u Ustavi 1835-1903, str. 226-228.

${ }^{33}$ Detaljnije o ovom pitanju videti: Jovan Lovčević, Nauka o financijama, Zagreb 1946, str. 64-67.

${ }^{34}$ Zakon o uređenju Glavne kontrole sa Pravilima za izvršenje ovog zakona, Beograd 1897.
} 
izvršenje Zakona (1892), koja su nešto kasnije zamenjena Pravilima za izvršenje Zakona (1897). ${ }^{35}$ Ova pravila su zamenjena novim Pravilima za izvršenje Zakona o uređenju Glavne kontrole (1897, sa izmenama i dopunama 1898, 1902, 1903). ${ }^{36}$

Zakonodavac je već u svom prvom članu preuzeo odredbu Ustava iz 1888, kojom je još jednom „uredio“ pravni položaj Glavne kontrole. Ona je uspostavljena radi „pregleda državnih računa i računa koji stoje pod nadzorom države“, ona je „zasebno nadleštvo“ i „računski sud“. Glavna kontrola nije bila organizacija sa svojstvom pravnog lica, ali je imala određeni stepen samostalnosti unutar ministarstva finansija, svojstvo računskog suda i elemente posebne državne službe. Glavna kontrola je imala svoj pečat.

U pogledu unutrašnje organizacije, Glavna kontrola je bila organizovana kao posebno nadleštvo, što je njenu organizaciju činilo jedinstvenom, ali i jednostavnom, jer nije bila organizovana u odeljenja. Zbog toga se može konstatovati da je njena organizacija bila jedinstvena celina. Bila je organizovana na teritorijalnom principu i posedovala je određenu teritorijalnu organizaciju. Najpre je u njenom sastavu bila mesna, okružna i sreska kontrola, a nešto kasnije (1897) samo mesna kontrola.

Kakav je bio sastav Glavne kontrole? Shodno odredbama Ustava iz 1888, Glavna kontrola je imala predsednika i četiri člana, koje je birala Narodna skupština sa liste kandidata koju je sastavljao Državni savet. Članovi su imali status sudije Kasacionog suda, a predsednik status državnog savetnika, tj. člana Državnog saveta. Izabrana lica bila su postavljana na dužnost kraljevim ukazom na predlog predsednika Ministarskog saveta. Izmenama predmetnog zakona (1897), izvršeno je preciziranje da predsednik Glavne kontrole ima položaj i platu člana Državnog saveta, a njeni članovi položaj, platu i periodičnu povišicu sudije Kasacionog suda.

Zakonom o uređenju Glavne kontrole preuzeta su ustavna rešenja o uslovima za izbor lica za predsednika i članove Glavne kontrole. Nažalost, kraljevskim ukazom (1894) bila je anulirana zakonska (i ustavna) odredba kojom se predsedniku i članovima Glavne kontrole garantovala „nepokretnost u njihovim zvanjima“. Takođe, bilo je predviđeno da predsednik i članovi, pre stupanja na dužnost, moraju da polože zakletvu kao sudije.

Predsednik je po položaju bio starešina Glavne kontrole, a njegova glavna prava i dužnosti prema personalu bila su određena zakonom. Predsednika je za slučaj njegove sprečenosti zastupao najstariji član Glavne kontrole. Za vođenje poslova Glavne kontrole bio je zadužen sekretar, sa položajem i pravima sekretara Apelacionog suda, a za pregled računa potreban broj računoispitača, arhivara, pisara i praktikanata.

Računoispitač je mogao biti neko ko je prethodno položio ispit za ovo zvanje pred komisijom i po pravilima koja je utvrđivala Glavna kontrola, uz podnošenje dokaza da ispunjava zakonske uslove.

Zakonodavac je, s jedne strane, preuzeo ustavne odredbe o nadležnostima Glavne kontrole, a s druge, dodatno ih je razradio i proširio. Sve funkcije Glavne kontrole mogle su se podeliti u četiri grupe, i to: 1) računske, 2) sudske, 3) administrativne i 4) budžetske. ${ }^{37}$

\footnotetext{
${ }^{35}$ Pravila za izvršenje Zakona o uređenju Glavne kontrole od 1. maja 1892 godine sa izmenama od 29. juna 1893. i 11. jula 1897. (na osnovu tač. 11. čl. 18, čl. 58. i tač. 2. čl. 95 istog zakona), Beograd 1897.

${ }^{36}$ Mihailo llić, Zakon o Glavnoj kontroli s dodatkom: Uredba o organizaciji Glavne kontrole, Pravila za izvršenje zakona o uređenju Glavne kontrole, Pravila o polaganju ispita za računoispitače Glavne kontrole, i Pravila o polaganju ispita iz dvojnog knjigovodstva za činovnike Glavne kontrole, Beograd 1926, str. 98-157.

${ }^{37}$ Kosta Kumanudi, op. cit., str. 139.
} 
Računske funkcije - Polazeći od računskih funkcija, Glavna kontrola je bila organizovana „kao osobeno nadleštvo“. Ove funkcije su bile administrativno-finansijske prirode i ogledale su se u jednoj naročitoj vrsti nadzora pod koji je potpadala celokupna administracija. Pod računske funkcije Glavne kontrole potpadao je nadzor gotovo svih državnih računa i celokupna državna imovina. Glavna kontrola je svoje računske funkcije vršila na taj način što je pregledala, ispravljala i likvidirala račune opšte administracije i svih računopolagača prema državnoj kasi i što je svom pregledu podvrgavala i svu državnu imovinu i dugovanja. Računi i imovina delili su se u dve grupe: neposredno državni (centralna i lokalna uprava) i posredno državni (fondovi i udruženja).

Kod realizovanja računskih funkcija pravila se razlika između, s jedne strane, pregleda računa i s druge, pregleda kasa, stvari i materijala. Za pregledanje računa zakonodavac je u Zakonu o uređenju Glavne kontrole predvideo dva sistema, i to: sistem centralizacije i sistem decentralizacije, koji su se međusobno kombinovali i dopunjavali. Odatle i dva uspostavljena sistema nadzora: aprobativni, nad već likvidiranim-svršenim računima i, drugi, preventivni, nad tekućim računima. Bilo je stavljeno u dužnost svim računopolagačima da svoje račune po završetku računske godine zaključe i na pregled podnesu Glavnoj kontroli, najkasnije do kraja aprila naredne godine.

Glavna kontrola bila je ovlašćena da vrši pregled računa neposredno ili preko mesne kontrole. Samo ispravnim računima Glavna kontrola je izdavala "razrešnicu“.

U pogledu pregleda kasa, stvari i materijala, pravila se razlika između dve vrste pregleda koje je Glavna kontrola preduzimala neposredno, i to: redovni pregled i vanredni pregled.

Sudske funkcije - Ove funkcije za Glavnu kontrolu nisu bile predviđene na osnovu prvodonete uredbe o njenom uređenju (1844). Glavna kontrola je po prvi put postala računski sud na osnovu uredbe iz 1858. Po ustrojstvu iz 1860., Glavna kontrola je izgubila svoje sudske nadležnosti. Sudska vlast je definitivno bila vraćena Glavnoj kontroli na osnovu uredbe iz $1862 .^{38}$

Iz računskih funkcija Glavne kontrole razvile su se njene sudske funkcije. One su vršene od Glavne kontrole na dva načina: u obliku presude o računima i u obliku izricanja disciplinskih kazni. U postupku pregledanja računa, kasa i stvari cilj je bio da se utvrdi u kakvom se stanju nalazi državna imovina. Ukoliko se pronađe da je ono ispravno, Glavna kontrola je to samo konstatovala razrešnicom koju je izdavala računopolagačima i rukovaocima. Međutim, ukoliko je ustanovila neke nepravilnosti, u tom slučaju je po zakonu morala preduzeti dalje mere da se naknadi šteta i obezbede potraživanja države prema određenim licima za pričinjenu štetu.

U sprovođenju postupka Glavne kontrole suđenja o ispravnosti računa, kasa i stvari mogu se identifikovati dve faze: faza pregledanja računa i faza rešavanja, tj. odlučivanja o pregledanim računima. Ovaj postupak bio je na detaljniji način uređen zakonom. Pravo disciplinskog kažnjavanja bilo je prvenstveno u nadležnosti predsednika Glavne kontrole, uz zakonsko ograničenje na ukor i novčano kažnjavanje od plate za pola meseca, i protezalo se na unutrašnji službeni red. Međutim, za teže krivice u vezi sa računima ili naredbama, i za teže kazne (npr. oduzimanje od plate tri meseca), bila je nadležna Glavna

\footnotetext{
${ }^{38}$ Ibid, str. 143
} 
kontrola. Ona je kazne izricala na opštoj sednici. Članovi Glavne kontrole potpadali su pod disciplinsku vlast Kasacionog suda, po podnetoj tužbi predsednika Glavne kontrole ili predsednika Ministarskog saveta.

Administrativne funkcije - Ove funkcije Glavne kontrole mogu se posmatrati kroz dve vrste: jedne su bile u vezi sa računskim i finansijskim nadležnostima Glavne kontrole, a druge su regulisale odnose između Glavne kontrole i Državnog saveta, ministarstava i drugih organa uprave.

Budžetske funkcije - O ovim funkcijama Glavne kontrole se ne može posebno govoriti sve do uredbe iz 1862, jer nije bilo posebnih odredaba, osim što je u svom godišnjem izveštaju Državnom savetu samo konstatovala stanje pregledanih računa. Tek donošenje pomenute uredbe, Glavna kontrola je bila dužna da za svaku budžetsku godinu, najdalje za tri godine od njenog završetka, sastavi i podnese pregled Državnom savetu o celokupnom državnom računovodstvu i da izloži kretanje prihoda i rashoda. ${ }^{39}$

Polazeći od sadržine Zakona o uređenju Glavne kontrole, njene budžetske funkcije su se ogledale u: sastavljanju budžeta, izvršenju budžeta i usvajanju završnog računa. Završni račun se upućivao Narodnoj skupštini od strane ministra finansija istovremeno kad i predlog budžeta za narednu godinu. Međutim, pre njegovog dostavljanja o završnom računu je „rešavala“ Glavna kontrola. Ona je primljeni završni račun pregledala i overavala, konačnu razrešnicu je davala Narodna skupština njegovim odobrenjem. Izveštaje za Narodnu skupštinu su bili dužni da potpišu predsednik i svi članovi Glavne kontrole.

Glavna kontrola je bila dužna da svoje primedbe dostavlja dotičnim ministrima po svim pitanjima koja se tiču državnog računovodstva. A ministrima je zakonodavac stavio u dužnost da sva pravila i naredbe koje se tiču knjigovodstva ili računovodstva propisuju posle saslušanja Glavne kontrole.

Kada Glavna kontrola izda razrešnicu na pregledane račune, tj. odobri ih, novi pregled računa je morao da usledi samo u dva zakonom određena slučaja: kad se pojavila greška u pregledanom računu i ako se pojavila zloupotreba od strane računoispitača ili računopolagača. Zakonom nije bilo dopušteno da se traži novi pregled odobrenih računa, ukoliko je proteklo 10 godina od njihovog odobrenja.

Pod disciplinsku odgovornost potpadali su računopolagači, računoispitači i sva ostala lica preko kojih je Glavna kontrola vršila svoju službu po računima, pod uslovima i na način određenim zakonom. Disciplinske kazne bile su: ukor i novčana kazna do tri meseca plate, koje je izricala Glavna kontrola na svojoj opštoj sednici, a za lica koja su bila izvan njenog domašaja bila je dužna da obavesti nadležnog ministra. Protiv izrečenih disciplinskih kazni nije bilo mesta žalbi.

Osim Zakona o uređenju Glavne kontrole, u ovom periodu je doneta i Uredba o organizaciji Glavne kontrole (1919). Nepune dve godine kasnije, izvršena je njena dopuna (1921). NJenom sadržinom su bliže uređena organizaciona pitanja Glavne kontrole. Na osnovu ove uredbe, doneta su Pravila o polaganju ispita iz dvojnog knjigovodstva za članove Glavne kontrole (1920).

\footnotetext{
${ }^{39}$ Ibid, str. 149.

${ }^{40}$ Mihailo llić, op. cit., str. 83-89 i 95-97.
} 


\section{Pravna priroda Glavne kontrole}

Potreba za postojanjem naročite kontrole u svojstvu državnog organa poticala je iz same prirode javnih prihoda i rashoda. Zbog toga je "glavna kontrola“ postojala u svim državama, i to pod različitim nazivima i sa različitom organizacijom. Svakako, ona je bila drugačija u apsolutnim monarhijama, u kojima češće nije bilo razlike između državne blagajne i privatne kase monarha, u odnosu na predstavničke države, u kojima su narodna predstavništva odobravala budžet o državnim prihodima i rashodima, i u isto vreme imala manji ili veći stepen nadzora u tadašnjem njihovom rukovanju. Taj nadzor se vršio delom neposredno, a delom preko naročitog kontrolnog nadleštva, koji se u nekim državama nazivao skupštinski odbor (npr. u Belgiji), čije je članove biralo narodno predstavništvo. ${ }^{41}$

$\mathrm{U}$ istorijskom kontekstu, polazeći od relevantnih ustavnih (1888) i zakonskih (1892) odredbi, koje su donete radi izvršenja ustavnih i zakonskih naređenja, Glavna kontrola u Srbiji je dovedena u funkcionalnu vezu sa Narodnom skupštinom, koja se ogledala kod kontrole budžeta, kako preventivne (u toku samog izvršenja budžeta - preko vize sa rezervom), tako i naknadne, koju je vršila Narodna skupština u vidu odluke o završnom računu. ${ }^{42} \mathrm{Za} \mathrm{razliku}$ od Srbije, pre udruživanja u državu SHS, status najviše računske kontrole u „prečanskim“ pokrajinama bio je drugačiji. Na primer, do raspada Austro-ugarske monarhije, u Sloveniji i Dalmaciji je službu vrhovne računske kontrole vršio Glavni („najvišji“) računski dvor, koji je bio uspostavljen Carskom („Česarskom“) naredbom (1866). Glavni računski dvor bio je neposredno podređen monarhu, a samostalan u odnosu na ministarstava; štaviše, „bio je sa ministarstvima u istoj ravni“. U njegov delokrug je ulazio, između ostalog, pregled svih računa državnih oblasti o prihodima i izdacima i sastavljanje završnog računa. Međutim, pod njegovu nadležnost nisu potpadali pregled i odobravanje računa o državnim dugovima, jer su oni bili u nadležnosti posebne komisije. Bitna razlika između Glavne kontrole i Glavnog računskog dvora u pogledu kontrole nad izvršenjem budžeta ležala je u tome da Carska naredba nije priznavala prethodnu (preventivnu) kontrolu, već je delovanje Glavnog računskog dvora bilo usredsređeno na naknadnu (aprobativnu, detektivnu) kontrolu. Preventivnu kontrolu su vršili računska odeljenja naredbodavnih oblasti, koja nisu bila organ Glavnog računskog dvora, već su službeno i disciplinski bili neposredno podređeni naredbodavcu. ${ }^{43}$

\section{Period od uspostavljanja Kraljevine Srba, Hrvata i Slovenaca i Kraljevine Jugoslavije do završetka Drugog svetskog rata}

U Kraljevini SHS Glavna kontrola je bila uređena Vidovdanskim ustavom (1921) i posebnim Zakonom o Glavnoj kontroli (1922). Takvo stanje je potrajalo do nastanka Kraljevine Jugoslavije, s tim da se u narednom periodu, sve do njene kapitulacije i završetka Drugog svetskog rata, ne može govoriti o bilo kojim oblicima revizije javnih rashoda. ${ }^{44}$

\footnotetext{
${ }^{41}$ Stojan Marković, op. cit., str. 415-416.

${ }^{42}$ Milan Radojković, op. cit., str. 57.

${ }^{43}$ H. Vodopivec, Predgovor, u Alek. Popović, op cit., str. 4-5.

${ }^{44}$ Bogoljub Vitorović, Revizija javnih rashoda u svetskoj teoriji i praksi i potreba za njenim uvođenjem u SR Jugoslaviji, Računovodstvo, br. 7-8/1998, str. 46.
} 
Vidovdanski ustav je Glavnu kontrolu zatekao, a nije je ustanovio, jer je ona postojala i vršila svoje nadležnosti od uspostavljanja ujedinjene države. „... ona se organski razvila iz srpske Glavne kontrole, a ova je opet jedno od najstarijih nadleštva obnovljene Srbije (ustanovljena 1844, a predviđena još u prvom srpskom Ustavu od 1835)“.45

Pravni položaj Glavne kontrole bliže je uređen Zakonom o Glavnoj kontroli (1922) i Pravilnikom o radu mesnih kontrola i komesara za vanredne preglede (1930). U suštini, odredbe ovog zakona su predstavljale preuzeta osnovna rešenja iz Zakona o uređenju Glavne kontrole (1892) Kraljevine Srbije, uz neznatne izmene i dopune.

Po proteku deset godina od donošenja Vidovdanskog ustava, donet je Ustav Kraljevine Jugoslavije (1931). Njegove osnovne karakteristike se ogledaju u sledećem: Kraljevina SHS prerasla je u Kraljevinu Jugoslaviju, koja više nije bila ustavna i parlamentarna država, već „ustavna monarhija“; zakonodavnu vlast su zajednički vršili kralj i narodno predstavništvo, koje je od ranijeg jednodomnog pretvoreno u dvodomno (Narodna skupština i Senat); kralju je dato ovlašćenje da u izuzetnim slučajevima, ukazom naredi da se privremeno preduzmu sve izvanredne, neophodno potrebne mere u celoj Kraljevini ili u jednom njenom delu, nezavisno od ustavnih i zakonskih naređenja i dr. U kontekstu Glavne kontrole, Ustav je preuzeo sve odredbe o njoj iz Vidovdanskog ustava.

Posle ubistva kralja Aleksandra I Karađorđevića u Marseju (1934), prilike u Kraljevini Jugoslaviji počele su postepeno da se liberalizuju, a državne poslove vodilo je namesništvo sa knezom Pavlom na čelu, u ime maloletnog kralja Petra II. Međutim, usledio je vojni udar 1941., kad je srušen namesnički režim i za vladaoca postavljen još uvek maloletni Petar II. Drugi svetski rat je zahvatio Kraljevinu Jugoslaviju, koja je za nepune dve nedelje bila vojno poražena. Time je ona prestala da postoji, čime je prestao i njen Ustav iz 1931.

U nastavku rada predmetni period možemo bliže sistematizovati i obraditi kroz sledeća pitanja: ustavno regulisanje Glavne kontrole; zakonsko i podzakonsko regulisanje Glavne kontrole; položaj i pravna priroda Glavne kontrole.

\section{Ustavno regulisanje Glavne kontrole}

Na sličan način kao i u ustavima iz 1888. i 1903, Glavna kontrola je bila predmet regulisanja i u Ustavu Kraljevine SHS (1921), uz određene izmene i preciziranja. Glavna kontrola je ovim ustavom po prvi put uspostavljena kao „vrhovni“ računski sud, što znači da je bila najviši organ u oblasti kontrole javnih prihoda i rashoda. Ovim ustavnim odredbama se nije utvrđivao broj članova Glavne kontrole, uređivao se način njihovog izbora, uz naređenje da polovinu članova moraju činiti pravnici. Iz ustavnih odredbi o Glavnoj kontroli se ne može više zaključiti o njenoj nezavisnosti i samostalnosti, uključujući i pitanje njenog pravnog položaja - da li je ona imala svojstvo pravnog lica. NJen predsednik i članovi su u pravnom položaju bili izjednačeni sa članovima Državnog saveta. Ustavom je bilo predviđeno donošenje posebnog zakona kojim bi se bliže uredila pitanja sastava, nadležnosti i postupka Glavne kontrole. ${ }^{46}$

\footnotetext{
${ }^{45}$ Laza Kostić, Komentar Ustava Kraljevine Jugoslavije od 3 septembra 1931, str. 268.

${ }^{46}$ Ustav za Kraljevinu Srba, Hrvata i Slovenaca od 1921., čl. 118, u Ustavi i vlade 1835-1941, str. 225-226.
} 
U okviru materije o Glavnoj kontroli, ustavotvorac je po prvi put uredio i pitanje podnošenja završnog državnog računa, sledećom formulacijom: „završni državni račun podnosi se Narodnoj skupštini na rešenje sa primedbama Glavne kontrole, i to najdalje za jednu godinu, računajući od završetka svake računske godine".

$\mathrm{Na}$ osnovu Vidovdanskog ustava, najpre, bilo je predviđeno „privremeno proširenje važnosti“ zakona Kraljevine Srbije na celokupnu teritoriju države SHS, uključujući i tada važeći Zakon o uređenju Glavne kontrole (1892), sa izmenama i dopunama koje bi bile izvršene na način predviđen ovim ustavom. ${ }^{47}$ Zatim, ustavom previđeni način je uspostavljen „radi ujednačavanja zakonodavstva i uprave“ u Kraljevini SHS, a predviđao je poseban skraćeni postupak za donošenje izmena i dopuna i pomenutog zakona o Glavnoj kontroli. ${ }^{48} \mathrm{Na}$ kraju, nove vlasti su se odlučile za donošenje novog Zakona o Glavnoj kontroli (1922), a ne za izmene i dopune Zakona o uređenju Glavne kontrole (1892), i to ne u redovnom postupku već u skraćenom. Zbog toga je u tadašnjoj literaturi postavljeno pitanje: da li je primena takvog postupka u ovom slučaju bila u saglasnosti sa Vidovdanskim ustavom. Štaviše, isticano je da je na osnovu formulacije odredbe čl. 133. Ustava trebalo doneti samo izmene i dopune, a ne novi zakon. Naprosto, novodoneti zakon nije mogao da ima za cilj izjednačavanje zakonodavstva, pošto je to izjednačavanje izveo sam Ustav „proširenjem srbijanskog zakona na celu zemlju“" 49

Posle Šestojanuarske diktature (1929), promenjen je pravni položaj Glavne kontrole, ali su njene funkcije ostale istovetne. Ukinuta je stalnost i nepokretnost predsednika i članova Glavne kontrole, jer ih je sada postavljao i smenjivao kralj, na predlog predsednika vlade. Takođe, vize sa rezervom saopštavale su se kralju, a izveštaji o državnom završnom računu podnošeni su kralju.

Ustav Kraljevine Jugoslavije (1931) je doneo kralj Aleksandar I Karađorđević, kao oktroisani ustav, dve godine posle zavođenja Šestojanuarske diktature. Zavođenjem diktature ukinut je Vidovdanski ustav i raspuštena Skupština izabrana 1927. U kontekstu našeg predmeta istraživanja, tzv. Septembarski ustav (1931) je preuzeo sve odredbe o Glavnoj kontroli iz Vidovdanskog ustava, uz izostavljanje dva stava vezana za bliža određenja i status predsednika i članova Glavne kontrole. ${ }^{50}$ Kako je isticao prof. Kostić, Ustav iz 1931. je Glavnu kontrolu zatekao, jer je ona postojala i vršila svoje funkcije od postojanja ujedinjenja države. ${ }^{51}$

Septembarskim ustavom je vraćen parlament, pa se i Glavnoj kontroli u značajnom stepenu vraća položaj, mesto i uloga koji je imala po Vidovdanskom ustavu. Važeći Zakon o Glavnoj kontroli (1922) nije bio usaglašen sa ovim ustavnim odredbama, ali je u praksi uspostavljena svojevrsna funkcionalna veza između Glavne kontrole i parlamenta, jer su u praksi viza sa rezervom i izveštaj o državnom završnom računu dostavljani parlamentu, a ne Kralju. Stalnost i nepokretnost predsednika i članova Glavne kontrole nije postojala.

\footnotetext{
${ }^{47}$ Ustav za Kraljevinu Srba, Hrvata i Slovenaca iz 1921, čl. 131.

${ }^{48}$ Ustav za Kraljevinu Srba, Hrvata i Slovenaca iz 1921, čl. 133. stav 1.

${ }^{49}$ Mihailo llić, op. cit., str. 7.

${ }^{50}$ Ustav Kraljevine Jugoslavije od 1931., čl. 107, u Ustavi i vlade 1835-1941, str. 263-264.

${ }^{51}$ Laza Kostić, Komentar Ustava Kraljevine Jugoslavije od 3 septembra 1931, str. 268.
} 


\section{Zakonsko i podzakonsko regulisanje Glavne kontrole}

Zakon o Glavnoj kontroli donet je 1922, na osnovu Ustava Kraljevine SHS (1921), sa izmenama i dopunama (1929. i 1930). ${ }^{52}$ Po mišljenju pojedinih autora, noveliranje ovog zakona bila je nužna pretpostavka, jer je taj zakon bio sa slabostima u tehničkom smislu, nesistematičan, bez ustaljene terminologije, mestimično kazuistički a mestimično nedovoljno jasan i netačan, pa je na mnogim mestima ostavljao otvorena vrata za dvojstvo u tumačenju pojedinih odredaba. ${ }^{53} \mathrm{Na}$ osnovu odgovarajućih odredaba Zakona o Glavnoj kontroli, opšta sednica Glavne kontrole je propisala Pravilnik o radu mesnih kontrola i komesara za vanredne preglede (1930). ${ }^{54}$

Glavna kontrola bila je uspostavljena u tadašnjoj državi SHS kao „vrhovni računski sud“. Kako se zapaža, iako je nazvana računski sud, Glavna kontrola je bila samo manjim svojim delom „sud“, a mnogo više „pomoćni organ parlamenta“ u nadziranju vladinog izvršenja budžeta, što je inače bila njena najvažnija funkcija. ${ }^{55}$ Takođe, Glavna kontrola je uspostavljena i kao „osobeno računsko nadleštvo“ pri ministarstvu finansija, radi pregleda državnih, banovinskih i opštinskih računa i nadziranja nad izvršenjem njihovih budžeta, kao i radi otklanjanja protivzakonite upotrebe ili oštećenja materijalnih državnih, banovinskih i opštinskih sredstava i utvrđivanja njihove ispravnosti, zloupotrebe ili nepravilnosti, a s tim u vezi i utvrđivanje zakonske odgovornosti za zloupotrebe i naknadu štete. Pod vrhovni nadzor Glavne kontrole potpadali su i računi ustanova i korporacija sa državnom pomoći, osim ako za iste zakonom nije drukčije određeno. Iz napred navedenih zakonskih nadležnosti, proizlazi da je Glavna kontrola „otklanjala protivzakonitu upotrebu ili oštećenje materijalnih državnih sredstava“. Međutim, reč je o nepreciznoj zakonskoj formulaciji, jer ona nije imala navedena ovlašćenja, kako je inače proizlazilo iz sadržine predmetnog zakona. Naprosto, Glavna kontrola nije imala ovlašćenja da utvrđuje zakonsku odgovornost za zloupotrebe, već je to na osnovu Zakona bilo prepušteno istražnim i pravosudnim organima. $^{56}$

Kakav je bio sastav Glavne kontrole? Imajući u vidu da se Ustavom Kraljevine SHS nije ulazilo u pitanje broja članova Glavne kontrole, zakonodavac je predvideo da se ona sastoji od predsednika i 11 članova, znači ukupno 12. Međutim, u postupku donošenja ovog zakona bilo je prigovora da je predloženi broj članova prevelik, a u komisiji koja je radila na njegovom tekstu bilo je predloga da ovaj broj članova iznosi osam. ${ }^{57}$

Predsednik i članovi Glavne kontrole morali su da ispunjavaju zakonom određene uslove. NJih je postavljao Kralj svojim ukazom, na predlog predsednika Ministarskog saveta, a mogli su po istom postupku biti smenjeni sa svog položaja, prevedeni u drugu službu ili penzionisani. Treba konstatovati da je način biranja predsednika i članova Glavne kontrole

\footnotetext{
${ }^{52}$ Zakon o Glavnoj kontroli od 30. maja 1922 godine, sa izmenama i dopunama od 7. januara i 10. oktobra 1929. godine i 17. oktobra 1930. godine, sa Pravilnikom o radu mesnih kontrola i komesara za vanredne preglede, Beograd 1930.

${ }^{53}$ H. Vodopivec, Predgovor, u Alek. Popović, op. cit., str. 11-12.

${ }^{54}$ Pravilnik je objavljen u „Službenim novinama“ 12. decembra 1930.

${ }^{55}$ Alek. Popović, op. cit., str. 16.

${ }^{56}$ Mihailo llić, op. cit., str. 9-10.

${ }^{57}$ Ibidem.
} 
ostao isti kao i u prethodnom zakonu. Pri stupanju na dužnost predsednik i članovi Glavne kontrole bili su dužni da polože zakletvu na vernost Kralju i na zakonito vršenje službe.

Kakva je bila unutrašnja organizacija Glavne kontrole? Ona je bila organizovana u tri odeljenja (administrativno, računsko i sudsko), koja su obavljala „celokupni službeni posao Glavne kontrole“. Odeljenja su se delila na odseke, na čijem čelu su bili načelnici, a na čelu odseka šefovi sa potrebnim brojem pomoćnog osoblja. Bliže odredbe o unutrašnjoj organizaciji Glavne kontrole bile su propisane pravilnikom za izvršenje zakona.

Koji je bio delokrug rada Glavne kontrole? Osnovne nadležnosti Glavne kontrole, radi kojih je inače i uspostavljena, jesu one koje se tiču kontrole izvršenja državnog i samoupravnih budžeta, bilo pre samog izvršenja, bilo posle njihovog izvršenja. Po principu enumeracije nabrojane su nadležnosti Glavne kontrole. NJoj su stavljene u dužnost dva zadatka: 1) pregled računa opšte administracije i 2) nadzor nad izvršenjem budžeta. Zbog toga je njen delokrug bio dvojak, jer je pojedine poslove obavljala vršeći računsku kontrolu, a druge poslove, manje po obimu, kao računski sud.

Funkcije Glavne kontrole bile su: računska (redovni pregled računa i vanredni pregled kasa, stvari i materijala); sudska (sporovi o naknadi štete); administrativna (biranje administrativnog osoblja, propisivanje određenih pravila, overavanje vladinih izveštaja o izvršenju finansijskih ugovora i dr.) i budžetska (sastavljala je svoj budžet, vodila je nadzor nad izvršenjem državnog budžeta, pregledala je i overavala završni državni budžet). ${ }^{58}$

Glavna kontrola je komunicirala neposredno sa svim organima vlasti u vezi sa svim poslovima iz svoje nadležnosti. Na zahtev Glavne kontrole, sva nadleštva bila su dužna da joj dostave tražene podatke, akta ili isprave, koja su joj bila potrebna radi pregleda računa ili presuđenja nekog spornog predmeta.

Nakon donošenja budžeta, ministar finansija bio je dužan da ga u originalu dostavi Glavnoj kontroli, zajedno sa njegovim specijalnim delom, u kome su osim partija bile izložene i pozicije za svako nadleštvo i ustanovu.

Predsednik je bio starešina Glavne kontrole, a njegove dužnosti i prava bili su taksativno određene zakonom. Svi predmeti za koje je trebalo doneti odluku rešavali su se, odnosno presuđivali u opštim i redovnim sednicama Glavne kontrole.

Glavna kontrola je u postupku vršenja kontrole donosila tri pojedinačna pravna akta: vizu, vizu s rezervom i razrešnicu. Viza je akt kojim je Glavna kontrola vršila preventivnu kontrolu u postupku izvršavanja budžeta. Po svojoj sadržini, ona je predstavljala pisanu izjavu od strane nadležnog organa Glavne kontrole da je jedan konkretan izdatak zakonit i saglasan sa donetim budžetom, i da se može izvršiti. Treba naglasiti da se viza odnosila samo na izdavanja, i to u toku izvršenja konkretnog budžeta. S druge strane, pravilnost primanja i izdavanja, kod pregleda i rasprave završnih računa, nije povlačila vizu, već razrešnicu. Viza je imala pravnu prirodu pojedinačnog pravnog akta sa određenim pravnim dejstvom. Ona je imala uticaj samo na dalju sudbinu odluke na koju je data, jer je tu odluku činila izvršnom. Zbog toga prof. Stjepanović konstatuje da je „viza uslov izvršnosti odluke“. ${ }^{59}$ Međutim, po prof. L. Kostiću, viza Glavne kontrole je akcesorni akt, u jednom kompleksnom (zbirnom) aktu, tj. viza je deo tog akta. ${ }^{60}$ Kod zbirnih akata izdvaja

\footnotetext{
${ }^{58}$ Alek. Popović, op. cit., str. 52-53.

${ }^{59}$ Nikola Stjepanović, Opšta teorija o Glavnoj kontroli Kraljevine Jugoslavije, Beograd 1938, str. 26.

${ }^{60}$ Laza Kostić, Administrativno pravo II, Beograd 1936, str. 103.
} 
se jedan koji je centralni (glavni), s tim da on u hronološkom smislu ne mora uvek biti poslednji. Ali, važnost glavnog akta uvek zavisi u potpunosti od važnosti ostalih njegovih sastavnih delova, tj. akata koji su akcesorne prirode. Odbijanje vize od strane Glavne kontrole nije imalo apsolutni karakter. Ono je samo odlagalo izvršenje, ali ga nije onemogućavalo definitivno, tj. imala je suspenzivno dejstvo. ${ }^{61}$

Za slučaj da Glavna kontrola nađe da je odluka koja se njoj neposredno dostavlja na ocenu i vizu protivna zakonu ili budžetu, ona je bila dužna da izvesti nadležnog ministra odnosno bana. Ukoliko oni ne usvoje mišljenje Glavne kontrole, mogli su u saglasnosti sa predsednikom Ministarskog saveta doneti odluku da je Glavna kontrola bila dužna da dâ tzv. vizu sa rezervom i da o tome odmah obaveste Narodno predstavništvo. ${ }^{62}$

Završne račune budžeta pregledala je, raspravljala i razrešavala Glavna kontrola. Ti računi su bili predmet pojedinačnog pravnog akta koji je zakonodavac nazivao razrešnica. Po svojoj sadržini, razrešnica je takav pravni akt kojim je Glavna kontrola konstatovala da jedan državni, banovinski ili opštinski račun, koji je bio predmet njenog pregleda i rasprave, ispravan. Davanjem razrešnice su se računopolagači i naredbodavci „razrešavali“ materijalne odgovornosti za preduzete radnje u postupku izvršenja konkretnog završnog računa. Zbog toga se s pravom konstatuje u literaturi da je pravna snaga razrešnice ustanovljena ne samo u opštem interesu, već i u interesu odgovornih lica kojima se ona izdaje. Pravni značaj razrešnice ogleda se u tome što su se lica odgovorna po razrešenom računu štitila od zahteva za ponovno podnošenje i pregled tog računa. ${ }^{63}$

U postupku rasprave završnih računa, a naročito u postupku pregleda kasa (blagajni) i materijala, ovlašćena lica su mogla da konstatuju određene zloupotrebe pa i učinjena krivična dela, npr. utaje, falsifikati i dr. U takvim slučajevima Glavna kontrola nije bila nadležna da raspravlja o krivičnom sporu koji bi iz pronađenog stanja mogao nastati, ali je bila dužna da podnese krivičnu prijavu nadležnom organu protiv odgovornog lica.

Glavna kontrola kao računski sud imala je dužnost da u redovnim sednicama raspravlja sporove o naknadi štete. Redovna sednica je izricala presude i rešenja u ime Kralja. Za podnošenje tužbe po svim računima bilo je nadležno sudsko odeljenje, a tužba se dostavljala tuženom po odredbama građanskog sudskog postupka, a samo izuzetno, kada je zakonom bilo određeno, taj postupak nije bio javan i vodio se u pisanoj formi. Odluku redovne računske sednice, da se ima podići tužba za naknadu štete, izvršavao je načelnik sudskog odeljenja. Njega su u praksi zvali kontrolni državni tužilac. Podizao je građansku tužbu protiv označenog lica za utvrđenje sume kod redovne sudeće sednice Glavne kontrole.

Glavna kontrola pri raspravljanju sporova za naknadu štete „nije sudila samo račune nego i odgovorna lica“, tj. ulazila je u subjektivne momente koji utiču na postojanje ili nepostojanje odgovornosti za utvrđenu štetu. Zbog takvog pristupa u ostvarivanju svojih nadležnosti, Glavna kontrola se u mnogome razlikovala od francuskog računskog suda koji je "sudio samo račune“, tj. donosio odluke samo na osnovu objektivnih elemenata iz računa, a nije mogao da ulazi u ponašanje odgovornih lica. ${ }^{64}$

\footnotetext{
${ }^{61}$ Nikola Stjepanović, op. cit., str. 27.

${ }^{62}$ Zakon o Glavnoj kontroli (1922), čl. 59.

${ }^{63}$ Nikola Stjepanović, op. cit., str. 33.

${ }^{64}$ Nikola Stjepanović, op. cit., str. 38.
} 
Iskustva i pouke iz prošlosti

Posle završetka budžetske godine, u zakonom određenom roku, ministar finansija je bio dužan da sastavi i podnese Narodnom predstavništvu na rešenje državni završni račun. U njemu je trebalo da pokaže rezultate celokupnog državnog gazdovanja u toku predmetne budžetske godine. $U$ istorijskom kontekstu, jedna od suštinskih razlika između Carske naredbe (1866), koja se primenjivala u prečanskim pokrajinama Kraljevine SHS, i Zakona o Glavnoj kontroli Kraljevine SHS (1922) ogledala se u izradi završnog računa. Dok je po austrijskom propisu završni račun sastavljao Glavni računski dvor, dotle je na osnovu Zakona o Glavnoj kontroli proizlazilo da je izrada završnog računa bila u nadležnosti ministarstva finansija. ${ }^{65}$ Državni završni račun je prethodno morao biti dostavljen Glavnoj kontroli radi njegove overe tačnosti s računske strane i podnošenja izveštaja o zakonitosti i ispravnosti primanja i izdavanja državnog novca i rukovanja državnom imovinom, sa eventualnim primedbama. ${ }^{66}$ Glavna kontrola je ovaj zadatak rešavala kao kolegijalni organ, na opštoj sednici, donošenjem dva akta: overa državnog završnog računa i sastavljanje izveštaja o njemu. Akt overe vršio se na samom državnom završnom računu i njime se tvrdilo da je račun veran stanju koje se nalazi u knjigama ministarstva finansija, tj. da je overa po svojoj sadržini materijalni akt - rezultat materijalnog tvrđenja, dokumentovanja, uveravanja. Zbog toga se overa u pravnoj teoriji kvalifikuje i kao „sastavni deo državnog završnog računa, akcesorni akt jednog zbirnog akta“. A pravni značaj overe ogleda se u tome što ministar finansija bez tog akta odnosno radnje ne može da podnese državni završni račun parlamentarnoj vlasti na dalji postupak. Izveštaj o zakonitosti i pravilnosti državnog završnog računa je poseban akt Glavne kontrole, koji u sebi sadrži i materijalna tvrđenja i pravne ocene. Međutim, „po svojoj unutrašnjoj prirodi i pravnom efektu nije pravni akt, nego materijalna radnja - stručno mišljenje“. ${ }^{67}$

\section{Položaj i pravna priroda Glavne kontrole}

Pravni položaj Glavne kontrole uspostavljen je Ustavom Kraljevine SHS (1921), Zakonom o Glavnoj kontroli (1922) i Pravilnikom o radu mesnih kontrola i komesara za vanredne preglede (1930). Kako je pravilno zapaženo, odredbe navedenog zakona su u suštini preuzeta osnovna rešenja iz Zakona o uređenju Glavne kontrole (1892) Kraljevine Srbije, uz male i neznatne izmene i dopune. ${ }^{68}$

U predratnoj Jugoslaviji, najpre je donet Zakon o državnom računovodstvu 1910, a zatim još jedan Zakon o državnom računovodstvu, 1934., koji nikad nije stupio na snagu. Ali, odredbe pomenutog zakona poslužile su za donošenje Uredbe o državnom računovodstvu (1941), kojom su bila regulisana sva pitanja o budžetu - donošenje, izvršenje i kontrola. Donošenjem navedene uredbe prestao je da važi Zakon o državnom računovodstvu (1910), a njene odredbe su predstavljale jedini propis u oblasti budžetiranja sve do posle Drugog svetskog rata, kad su doneta dva nova propisa: Zakon o kontrolno-računskoj komisiji ${ }^{69}$ i Zakon o državnom budžetu. ${ }^{70}$

\footnotetext{
${ }^{65}$ H. Vodopivec, Predgovor, u Alek. Popović, op. cit., str. 7.

${ }^{66}$ Zakon o Glavnoj kontroli, čl. 26. st. 1. tač. 13.

${ }^{67}$ Nikola Stjepanović, op. cit., str. 42-43.

${ }^{68} \mathrm{H}$. Vodopivec, Predgovor, u Alek. Popović, op. cit., str. 3.

${ }^{69}$ Zakon o kontrolno-računskoj komisiji, „SI. list DFJ“, br. 21/1945.
} 
Najpre, da istaknemo da je Glavna kontrola bila u funkciji budžetskog prava i unapređenja javne uprave. Ona je uspostavljena kao poseban organ koji je nadležan da vrši kontrolu nad prihodima i rashodima državne uprave, pošto skupština nije u stanju da to neposredno čini, iz tehničkih, stručnih, kadrovskih, organizacionih i drugih razloga. Iz navedenih razloga, skupština je bila prinuđena da kontrolu državnog budžeta prenese u nadležnost posebnog državnog organa.

Glavna kontrola je ustavom i zakonom uspostavljena kao „vrhovni računski sud“. I u pravnoj teoriji je isticano da ona postoji kao računski sud $i$ „,kontrolni organ finansijske administracije“." Pojedini autori nalaze za potrebno da istaknu da Glavna kontrola nije bila upravno nadleštvo u opštem smislu reči, „već je u nekim funkcijama strogo sudski, a u ostalim, posebno računskim poslovima, sudsko-upravni organ“. ${ }^{72}$

$\mathrm{U}$ organizacionom smislu, formalno i organizaciono, Glavna kontrola je „spadala u upravnu vlast“ ${ }^{73}$ jer je bila organizovana pri ministarstvu finansija, u okviru 3 odeljenja: administrativno, računsko i sudsko. Predsedniku i članovima Glavne kontrole zakonodavac je „obezbeđivao nezavisnost prema upravnoj vlasti“ priznavajući im sudsku stalnost i nepokretnost u položaju. ${ }^{74}$ I za premeštaj činovnika bio je po Zakonu o Glavnoj kontroli potreban njihov pristanak i pristanak Glavne kontrole. Samo u slučaju kad je predlog o premeštaju potekao od opšte sednice Glavne kontrole, on se mogao izvršiti i bez pristanka činovnika.

Nezavisno od napred iznetog, potrebno je da se nešto detaljnije zadržimo u traganju za odgovorima na sledeća pitanja: kakvo je mesto Glavne kontrole u tadašnjoj državnoj organizaciji vlasti, polazeći od principa podele vlasti? U koju vlast spada Glavna kontrola? Da li je reč o nekoj zasebnoj, četvrtoj vlasti, u kontekstu principa podele vlasti? $\mathrm{Na}$ osnovu već izvršenog istraživanja u pravnoj teoriji, polazeći od unutrašnje sadržine akata koje je donosila Glavna kontrola i njihove pravne prirode, prof. Stjepanović je konstatovao da je ona u vršenju svojih nadležnosti manifestovala sve tri državne funkcije - zakonodavnu (normativnu), upravnu i sudsku. ${ }^{75}$ Međutim, ova karakteristika nije specifična samo za Glavnu kontrolu, jer se ona proteže i na nosioce upravne, sudske i zakonodavne vlasti, polazeći od toga da vršeći svoje glavne funkcije vrše uzgred i druge dve funkcije. I prof. Kumanudi nalazi za potrebno da konstatuje sledeće: iako je Glavna kontrola raspolagala širokim obimom vlasti (nadzornom, sudskom i administrativnom), njene donete odluke nisu bile u poslednjem stepenu; jer je po svojim sudskim funkcijama ona stajala ispod Kasacionog suda, a po svojim administrativnim funkcijama pod aktivnom administracijom; u tome se i ogledala suštinska razlika između Glavne kontrole i Državnog saveta, koji je, vršeći takođe administrativne i sudske funkcije, dominirao nad aktivnom administracijom i nije zavisio od Kasacionog suda. ${ }^{76}$

U određivanju mesta Glavne kontrole kao celine u državnoj organizaciji Kraljevine Jugoslavije u pravnoj teoriji se polazilo od dva momenta, koje treba uzimati istovremeno, i

\footnotetext{
${ }^{70}$ Zakon o državnom budžetu FNRJ, „SI. list FNRJ“, br. 91/1945.

${ }^{71}$ Laza Kostić, Komentar Ustava Kraljevine Jugoslavije od 3 septembra 1931, str. 268.

${ }^{72}$ H. Vodopivec, Predgovor, u Alek. Popović, op. cit., str. 10.

${ }^{73}$ Laza Kostić, Komentar Ustava Kraljevine Jugoslavije od 3 septembra 1931, str. 247.

${ }^{74}$ Mihailo llić, op. cit., str. 13.

${ }^{75}$ Nikola Stjepanović, op. cit., str. 100-106.

${ }^{76}$ Kosta Kumanudi, op. cit., str. 148-149.
} 
to: 1) od osnovnih nadležnosti (zadacima, atribucijama) Glavne kontrole, radi kojih je ona ustanovljena i 2) od funkcionalno-organizacionog momenta pri vršenju njenih nadležnosti. $^{77}$ Osnovne nadležnosti Glavne kontrole bile su: pregled i likvidiranje završnih računa, preventivna kontrola izvršenja budžeta, overa i pregled završnog državnog računa pre njegovog podnošenja Narodnom predstavništvu. ${ }^{78}$ Glavna kontrola je u vršenju svojih osnovnih nadležnosti donosila određene akte, i to: vizu, vizu s rezervom, razrešnicu, overu i izveštaj o državnom završnom računu. Tim aktima su objekti bili različiti oblici delatnosti upravne vlasti, u kontekstu izvršenja budžeta. Zbog toga, prof. Stjepanović u svom istraživanju konstatuje da „Glavna kontrola pri donošenju ovih akata i formalno i funkcionalno-organizacijski stoji izvan upravne vlasti“" ${ }^{79}$ odnosno njoj nije mesto i ne predstavlja upravnu vlast. Takođe, u prilog svog stava iznosi i dodatnu tvrdnju: Glavna kontrola nije suverena ni u jednom od njenih osnovnih akata, u smislu da je njena volja u realizovanju zadataka bila definitivno odlučujuća, što predstavlja razlog da iznese zaključak da "ona nije zasebna vlast, pored zakonodavne, sudske i upravne“. ${ }^{80}$ Zbog svega toga, isti autor zaključuje da je Glavna kontrola, na osnovu realizovanja svoje osnovne nadležnosti i donošenja svojih glavnih akata, u funkcionalno-organizacionom smislu bila u vrlo tesnoj vezi sa zakonodavnom vlašću: Glavna kontrola je bila nekad neka vrsta mandatara ili reprezenta, a nekad tehnički i pomoćni organ. Tako, kod vize i vize sa rezervom, Glavna kontrola je bila mandatar zakonodavne vlasti; kod državnog završnog računa tehnički i pomoćni organ; a kod razrešnice reprezent zakonodavne vlasti. Zakonodavnoj vlasti je pripadalo pravo da pored odobravanja budžeta upravnoj vlasti daje i poslednju reč o izvršenju budžeta u njegovoj celini. Treba ukazati i na okolnost da je zakonodavna vlast imala uticaja u postavljanju predsednika i članova Glavne kontrole. $\mathrm{Na}$ osnovu izloženog, prof. Stjepanović iznosi stav da je „Glavnoj kontroli kao celini bilo (bi) mesto uz zakonodavnu vlast“. Ona u ovu vlast nije potpuno „utonula“ da bi postala njena kancelarija, ali je kao celina izvan upravne i sudske vlasti, iako su njeni glavni akti po svojoj prirodi bili administrativni a njena organizacija i način poslovanja slični, gotovo identični sudskoj vlasti. ${ }^{81}$

Glavna kontrola nije imala svojstvo subjekta prava, tj. svojstvo pravnog lica, jer je bila organizaciono smeštena u okvirima upravne vlasti, kao „osobeno računsko nadleštvo“, pri ministarstvu finansija. Zbog napred konstatovanog, ona je imala elemente posebne državne i javne službe. Glavna kontrola je imala svoj pečat. Glavnu kontrolu su činili predsednik i 11 članova, a od personala je imala sekretara, inspektora, načelnike odeljenja, šefove odseka, računoispitače i drugo osoblje. Predsednik je bio u statusu starešine Glavne kontrole.

$\mathrm{U}$ konceptualnom smislu, kod nas je usvojen belgijski sistem (neznatno ublažen), po kome je Glavna kontrola „pomoćni organ parlamenta u nadziravanju vladinog izvršenja budžeta“. Zbog toga je određivanje njenih članova stavljeno u nadležnost Narodne skupštine, a Kralju je ostavljeno samo formalno pravo njihovog postavljenja. ${ }^{82}$ Glavna kontrola

\footnotetext{
${ }^{77}$ Nikola Stjepanović, op. cit., str. 119.

${ }^{78}$ Vidovdanski ustav (1921), čl. 107. i Zakon o Glavnoj kontroli, čl. 1.

${ }^{79}$ Nikola Stjepanović, op. cit., str. 120.

${ }^{80}$ Ibidem.

${ }^{81}$ Ibidem.

${ }^{82}$ Slobodan Jovanović, Ustavno pravo, Beograd 1924, str. 423.
} 
je bila pomoćni organ Narodnoj skupštini u kontroli finansiranja državne delatnosti. ${ }^{83}$ Ona je formirana sa osnovnim zadatkom da pregleda državne, banovinske i opštinske račune i da nadzire izvršenje njihovih budžeta. Bliže određeno, funkcije Glavne kontrole bile su: 1) ispitivanje tačnosti i pravilnosti knjiženja, tj. da li su sve blagajničke operacije pravilno sprovedene i obračunate u blagajničkim knjigama; 2) utvrđivanje da li su naplate iz državne blagajne vršene tačno prema datim nalozima; 3) ispitivanje da li su prilikom vršenja naplata i isplata ispunjene sve zakonske formalnosti. ${ }^{84}$

\section{Zaključak}

Možemo da konstatujemo da je DRI prešla svoj istorijski put porekla (1835), nastanka, uspostavljanja i razvoja, do današnjih dana, u vremenskom trajanju od nepuna dva veka. Pređeni put njenog razvoja bio je praćen određenim usponima, zastojima i padovima, neposredno zavisnim od društveno-ekonomskog i političkog uređenja koje je vladalo u društvenoj zajednici.

Republika Srbija i druge države nastale na prostorima bivše SFR Jugoslavije imaju dugu tradiciju u obrazovanju posebnog organa nadležnog za kontrolu rashoda državnog budžeta. Glavna računovodstvena kontrola postojala je u Srbiji još od sredine XIX veka, u vreme vazalne Kneževine Srbije. Prve odredbe o kontroli javnih rashoda nalazile su se u prvom Ustavu Kneževine Srbije iz 1835, a zatim su inovirane u Ustavu iz 1888. Kontrola javnih rashoda je organizaciono bila smeštena u okvirima tadašnjeg ministarstva finansija, gde je ostala sve do 1843, od kada prelazi u nadležnost zakonodavnog organa - Državnog saveta, gde ostaje do 1869. Nešto kasnije, svoju punu organizacionu formu kontrola dobija u Zakonu o uređenju Glavne kontrole (1892).

Zakonska rešenja o Glavnoj kontroli zadržana su sve do ujedinjenja u državu Srba, Hrvata i Slovenaca (1918). Nešto kasnije, Glavna kontrola je bila uređena tzv. Vidovdanskim ustavom (1921) i posebnim Zakonom o Glavnoj kontroli (1922), na osnovu kojeg je uspostavljena glavna kontrola javnih finansija. Takvo stanje je potrajalo do nastanka Kraljevine Jugoslavije (1929), s tim da se u narednom periodu, sve do njene kapitulacije i završetka Drugog svetskog rata, ne može govoriti o bilo kojim oblicima revizije javnih rashoda.

\section{Literatura}

[1] Andrić M. (2012) Revizija javnog sektora, Subotica.

[2] Vitorović B. (1998) Revizija javnih rashoda u svetskoj teoriji i praksi i potreba za njenim uvođenjem u SR Jugoslaviji, Računovodstvo, br. 7-8/1998, str. 42-61.

[3] Vujisić D. (1984) Zakon o Službi društvenog knjigovodstva, Savezni zakoni i podzakonski propisi s komentarom, Zagreb.

[4] Vidovič, Z., \& Milunović, M. (2017). Revizija svrsishodnosti poslovanja. Oditor - časopis za Menadžment, finansije i pravo, 3(2), 37-53.

[5] Dragojević D. (1994) Zakonski okviri revizije kod nas (zakonodavno regulisanje revizije), Knjigovodstvo, br. 6-7/1994, 152-165.

\footnotetext{
${ }^{83}$ Laza Kostić, Komentar Ustava Kraljevine Jugoslavije od 3 septembra 1931, str. 271.

${ }^{84}$ Milan Todorović, Nauka o finansijama, II Budžet, Beograda 1933, str. 241.
} 
[6] Dabić LJ. (2016) „Pravni položaj Državne revizorske institucije (u pravu državne revizije javnog sektora Republike Srbije)“, str. 621-650; u zborniku radova LJudska prava - između ideala i izazova sadašnjosti, Kosovska Mitrovica 2016.

[7] Duin, D., Krstić, D., Nešić, B., \& Kaluđerović, N. (2017). Revizija svrsishodnosti javnih nabavki budžetskih korisnika. Oditor - časopis za Menadžment, finansije i pravo, 3(3), 61-72.

[8] Jovičić M. (1988) Predgovor, u Ustavi Kneževine i Kraljevine Srbije: 1835-1903 (urednik: Miodrag Jovičić), Beograd: SANU.

[9] Janković D. (1988) Razvitak ustavnosti u Srbiji u XIX i početkom XX veka, u Ustavi Kneževine i Kraljevine Srbije: 1835-1903 (urednik: Miodrag Jovičić), Beograd: SANU, 1988.

[10] Jovanović S. (1924) Ustavno pravo, Beograd.

[11] Kostić L. (1934) Komentar Ustava Kraljevine Jugoslavije od 3 septembra 1931 (Jugoslovensko ustavno pravo), Beograd.

[12] Kostić L. (1936) Administrativno pravo II, Beograd.

[13] llić M. (1926) Zakon o Glavnoj kontroli s dodatkom: Uredba o organizaciji Glavne kontrole, Pravila za izvršenje zakona o uređenju Glavne kontrole, Pravila o polaganju ispita za računoispitače Glavne kontrole, i Pravila o polaganju ispita iz dvojnog knjigovodstva za činovnike Glavne kontrole, Beograd.

[14] Kumanudi K.(1921) Administrativno pravo, Beograd.

[15] Krbek I. (1961) Pravo Jugoslovenske javne uprave, II knjiga - Organizacija uprave i službenička prava, Zagreb.

[16] Leko V. (2008) Osnovne metodološke postavke državne revizije javnih sredstava“, str. 519-560; Grupa autora (ured. Vera Leko), Vrhovna državna revizija javnih sredstava, Beograd.

[17] Lovčević J. (1946) Nauka o financijama, Zagreb.

[18] LJušić R. (1990) O Ustavu od 1838. godine, u Zborniku radova Ustavni razvitak Srbije u 19. i početkom 20-tog veka, Beograd.

[19] Marković S.(1893) Administracija Kraljevine Srbije sa naročitim pogledom na Nauku o državi i državnoj upravi, Knjiga prva - Opšti deo, Beograd.

[20] Milojević I., Majstorović A. (2006) Državna revizija u Srbiji: stanje i perspektive, Revizor, br. 33/2006, str. 13-25.

[21] Mirković M. (1988) Ustav od 1903. godine, u Ustavi Kneževine i Kraljevine Srbije: 18351903 (urednik: Miodrag Jovičić), Beograd: SANU.

[22] Martić S. (1987) Kontrola i revizija, Beograd.

[23] Popović S. - Đorđević Ž. (1960) Upravno-računski spor i društveno knjigovodstvo, Beograd.

[24] Popović D. (1988) Ustav od 1835. godine - „Sretenjski ustav“, u „Ustavi Kneževine i Kraljevine Srbije: 1835-1903" (urednik: Miodrag Jovičić), Beograd: SANU.

[25] Radojković M. (1940)Kontrola budžeta (doktorska disertacija), Beograd.

[26] Stjepanović N. (1938) Opšta teorija o Glavnoj kontroli Kraljevine Jugoslavije, Beograd.

[27] Stojilković M. (1989) Funkcije i položaj Službe društvenog knjigovodstva (doktorska disertacija), Beograd.

[28] Subotić-Konstantinović N. (1996) Pravni status revizora u našem i uporednom pravu, Ekonomski anali, br. 130/1996, str. 67-74.

[29] Stojilković M. (2007) Stanje i perspektive razvoja državne revizije u Republici Srbiji, Računovodstvo, br. 9-10/2007, str. 26-36.

[30] Stanojević LJ., Vidovič Z. (2014) Revizija javnog sektora, Beograd.

[31] Todorović M. (1933) Nauka o finansijama, II Budžet, Beograda.

[32] Šušnjar S. (1995) Poveravanje javnih ovlašćenja, Pravni život, br. 9/1995, str. 731-737.

[33] Zorić, M., \& Jovanović, V. (2018). Pravno istorijska dimenzija društvenih nauka. Oditor časopis za Menadžment, finansije i pravo, 4(3), 128-136. 